\title{
The Reduced Effect of International Conservation Agreements: A New Zealand Case Study
}

\author{
Pip Wallace*
}

\begin{abstract}
Despite proliferation of law and policy directed at halting global biodiversity decline, it is a common concern that decline continues. Using a case study of six New Zealand birds, this article demonstrates reasons for the reduced effect of the law in the context of three international agreements: the Convention on Wetlands of International Importance; the Convention on Biological Diversity; and the Convention on Migratory Species of Wild Animals. The article concludes that the agreements are deficient in terms of obligation and consistency, and that these deficiencies are compounded by insufficient implementation and siloed approaches at the national level. Success is also compromised by the ways in which the law privileges resource use to the detriment of species due to insufficient environment standards, sectoral defences, and widespread externalities. Ironically for birds, mobility which in evolutionary terms has been a survival strategy, may become a liability in the Anthropocene.

KEYWORDS: Threatened species, wildlife protection, Ramsar, CBD, CMS
\end{abstract}

\section{INTRODUCTION}

Reconciling short-term interests with the need to create long-term benefits is a challenge in the Anthropocene. Continuing global biodiversity loss suggests that international laws are failing to produce the desired results. Reasons for this include: ineffective implementation at the national scale, lack of political will, inertia, insufficient technical knowledge and capacity, limited stakeholder collaboration, legal and juridical impediments, natural phenomena including climate change, lack of integration across sectors, the primacy of economic development and a failure to mainstream. ${ }^{1}$

* Senior Lecturer, Faculty of Arts and Social Sciences, University of Waikato. (pwallace@waikato.ac.nz)

1 Stuart Harrop, 'Living In Harmony with Nature? Outcomes of the 2010 Nagoya Conference of the Convention on Biological Diversity' (2011) 23 JEL 117; Stuart Harrop and Diana Pritchard, 'A Hard Instrument Goes Soft: The Implications of the Convention on Biological Diversity's Current Trajectory' (2011) 21 Global Environ Change 474; Nicholas Robinson, 'Reflecting on Rio: Environmental law in the Coming Decades' in Jamie Benidickson and others (eds), Environmental Law and Sustainability after Rio (Edward Elgar Publishing Ltd 2011) 24-26; Michael Bowman, 'International Treaties and the Global Protection of Birds Part II' (1999) 11 JEL 281, 298; Peter Herkenrath, 'Birds and the Convention on Biological Diversity: Can Ornithologists and Bird Conservationists Make a Difference?' (2001) 12 Bird 
This article is designed to complement this literature by considering these factors in the specific context of species which the international agreements strive to protect. The methods include literature and policy review, case law analysis and case studies. Six New Zealand birds are used to discuss the influence of three international treaties upon conservation. Although this is a context specific enquiry, the study resonates more widely due to the choice of three international migrant species, the common threats they face, and the broad applicability of the international agreements.

This form of enquiry is influenced by a seminal article by Professor Jonas Ebbesson exploring conservation law and methodology by reference to the movements, habits and habitats of the honey buzzard bird. ${ }^{2}$ This article uses the method to apply both internal and external approaches to the law, critiquing the existing international agreements and examining what they require in order to protect the given species.

The case study species were chosen for contrasting habitat and distribution as follows: kokako (forest species), dotterel (coastal species), black petrel (marine species) godwit (international migrant) and wrybill (riverine/wetland environment, internal migrant). The sooty shearwater was included to enable consideration of customary take. The range of different habitats and distribution enables consideration of different threats and legal responses, and a wider view of the implementation of the law.

New Zealand as a party to a wide range of international agreements, must comply with the agreements and where necessary, give full effect to them in the domestic law. ${ }^{3}$ There is no single agreement relating to the protection of animals, rather numerous instruments deal with their protection. The Convention on Wetlands of International Importance (the Ramsar Convention), the Convention on Biological Diversity (CBD) and the Convention on Migratory Species of Wild Animals (CMS) form the focus of this article as they are particularly relevant to the case study species. The effect of these three agreements is examined and the findings confirm a series of matters affecting the success of the international instruments. At the international level, the effect of the agreements is reduced due to the level of obligation imposed and at times a lack of consistency in treatment of endangered species both within and between the agreements. These matters are compounded at the national

Conserv Int 99; Susan Shearing, 'Biodiversity' in David Leary and Balakrishna Pisupati (eds), The Future of International Environmental Law (United Nations University Press 2010) 42, 48; Reed Noss and others, 'Bolder Thinking for Conservation' (2011) 26 Conserv Biol 1; Peter Sand, 'A Century of Green Lessons: The Contribution of Nature Conservation Regimes to Global Governance' (2001) 1 Int Environ Agree Politics Law Economics 33; Robert Boardman, The International Politics of Bird Conservation: Biodiversity, Regionalism and Global Governance (Edward Elgar 2006) Ch 8; Michael Rands and others, 'Biodiversity Conservation: Challenges Beyond 2010’ (2010) 329 Science 1298; Anthony Waldron and others, 'Targeting Global Conservation Funding to Limit Immediate Biodiversity Declines' (2013) 110 Proc Natl Acad Sci 12144; Donal McCarthy and others, 'Financial Costs of Meeting Global Biodiversity Conservation Targets: Current Spending and Unmet Needs' (2012) 338 Science 946; Alvin Chandra and Anastasiya Idrisova, 'Convention on Biological Diversity: A Review of National Challenges and Opportunities for Implementation’ (2011) 20 Biodiversity Conserv 3295.

2 Jonas Ebbesson, 'Lex Pernis Apivorus: An Experiment of Environmental Law Methodology' (2003) 15 JEL 15.

3 Ministry for the Environment 'Multilateral Environmental Agreements' < http://www.mfe.govt.nz/laws/ meas/> accessed 20 June 2015; Law Commission, A New Zealand Guide to International Law and its Sources (NZLC R34 1996) 2. 
level due to insufficient implementation, siloed approaches, lack of consistency, the privileging of resource use, and a need for more nuanced and effective spatial planning for protection of endangered species. The focus of this article is upon the international agreements and their implementation, as I have considered the more general problems with protection of endangered species in New Zealand elsewhere. ${ }^{4}$

\section{THE STATE OF BIRDS IN NEW ZEALAND}

Although species extinction is a natural process, ${ }^{5}$ the global rate at which birds are being lost is higher than at any other time in their evolutionary history ${ }^{6}$ and anthropogenic change of the environment is the key driver for this. ${ }^{7}$ A recent global assessment emphasises that 'the overarching driver of species extinction is human population growth and increasing per capita consumption'.

Boardman catalogues anthropogenic effects into three categories, direct (eg hunting), indirect (eg habitat fragmentation or introduced predators) and adaptation effects (eg adaptation to the human environment). ${ }^{9}$ Inhabiting an archipelago of more than 330 oceanic islands, in the south-western Pacific Ocean, New Zealand birds face similar threats to birds on a global scale such as habitat loss and modification, but due to evolution in the absence of mammalian predators are particularly threatened by alien invasive species. ${ }^{10}$ Species loss in New Zealand is accentuated by high levels of species endemism, ${ }^{11}$ and in contrast to global averages New Zealand levels of threatened species are elevated. ${ }^{12}$ At the generic level, compared with global statistics, New Zealand has a higher percentage of 'threatened' or 'at risk' bird species. Of $417 \mathrm{New}$ Zealand species, 77 (18.5\%) are 'threatened' and 92 (22.1\%) are 'at risk. ${ }^{13}$ In 2013 the global figures were $1,313(13.2 \%)$ threatened and $880(8.9 \%)$ near threatened. ${ }^{14}$

4 Pip Wallace, 'Boundaries of Absolute Protection: Distribution of Benefit and Harm to Birds through Law and Planning in New Zealand' (PhD thesis, University of Waikato 2014).

5 Alison Stattersfield, Leon Bennun and Martin Jenkins (eds), State of the World's Birds: Indicators for our Changing World (BirdLife International 2008) 15.

6 Kenneth Norris and Deborah Pain (eds), Conserving Bird Biodiversity: General Principles and their Application (CUP 2002) at ix.

7 Carsten Rahbek and Robert Colwell, 'Biodiversity: Species Loss Revisited' (2011) 473 Nature 288-89; Kate Grarock and others, 'Are Invasive Species Drivers of Native Species Decline or Passengers of Habitat Modification? A Case Study of the Impact of the Common Myna (Acridotheres Tristis) on Australian Bird Species' (2014) 39 Austral Ecol 106; Stacey Jupiter, Sangeeta Mangubhai and Richard Kingsford, 'Conservation of Biodiversity in the Pacific Islands of Oceania: Challenges and Opportunities' (2014) 20 Pacific Conserv Biol 206.

8 SL Pimm and others, "The Biodiversity of Species and their Rates of Extinction, Distribution, and Protection' (2014) 344 Science 1246752-1, 1246752-4.

9 Boardman (n 1) 14.

10 Kerry-Jane Wilson, The State of New Zealand's Birds 2008; Special Report; Conservation of Birds on the Mainland (OSNZ 2008).

11 RN Holdaway, 'New Zealand's Pre-Human Avifauna and its Vulnerability' (1989) 12 New Zeal J Ecol 18.

12 IUCN, Red List Table 1: Numbers of threatened species by major groups of organisms (1996-2013) (IUCN 2013) <http://www.iucnredlist.org/documents/summarystatistics/2013_1_RL_Stats_Table1.pdf > accessed 20 June 2015; Rod Hitchmough, Summary of Changes to the Conservation Status of Taxa in the 2008-11 New Zealand Threat Classification System Listing Cycle (Department of Conservation 2013) 4.

13 Hugh Robertson and others, Conservation Status of New Zealand Birds, 2012 (Department of Conservation 2013) 2.

14 BirdLife International, State of the World's Birds 2013: Indicators for our Changing World (2013) 7. 
Eradication of predators on off-shore islands and species management programmes have produced some notable conservation gains. However, areas lacking effective species management are less likely to produce such gains and the most recent NZ Department of Conservation report identifies greater numbers of bird species becoming more threatened rather than less. ${ }^{15}$ Causes of deterioration in status are thought to be changes in land-use, particularly conversion of sheep farming to dairy farming, changes in oceanic productivity, possibly linked with global warming, fisheries bycatch and predation or a combination of those named. ${ }^{16}$

Three of the study birds are considered 'threatened' under the New Zealand classification system, each with a listing of 'vulnerable' (black petrel, dotterel and wrybill). The remaining three fall within the 'at risk' category, although the qualifier of 'conservation dependent' for the kokako indicates that where intensive conservation management of this bird fails, the bird is also likely to fail. The godwit and the sooty shearwater are buffered by their significantly largely populations, but are still suffering significant losses within their ranges. ${ }^{17}$

The case study birds face a range of common threats as well as species-specific threats. Threats common to the case study species include predation by invasive alien mammals and habitat loss or change. These common threats, however, have characteristics particular to the bird species or habitat. For instance, the composition of the suite of predators limiting the New Zealand dotterel may be different to that of the kokako. Alternatively, the threat may be differentiated both within and between species dependent upon place. Additionally, the case study species may experience unique threats. For instance, the pelagic species, the sooty shearwater and black petrel are each threatened by fisheries bycatch, yet a particular fishery may be more damaging to one species than another and different methods of mitigation may need to be tailored to each species. As birds face species specific threats, conservation responses must be well tuned to the particular pressure. ${ }^{18}$ In other work I have established that case study bird habitat is lost or compromised by a wide range of activities in the landscape such as vegetation removal, wetland drainage, reclamation, point source and non-point source pollution, water level change, spatial occupation through development of structures and obstacles, presence of machinery, and human disturbance. The extensive and complex threats starkly demonstrate the complex nature of the problem to which the law must respond.

The mobility of birds in the land and seascape deepens these challenges, as static protective reserves may prove insufficient in terms of extent and representativeness. Ironically, mobility which in evolutionary terms has been a survival strategy may become a liability in the Anthropocene. Of the case study birds, only the kokako (a poor flier) is largely confined to protective reserves, within which its conservation status is generally improving due to habitat protection and conservation management. The failure of the case study species to thrive in the working lands beyond protective reserves and pest proof fences signifies a serious loss of balance in the 
New Zealand landscape. Bycatch in the marine environment presents a similar issue for birds such the black petrel and sooty shearwater, which may breed within protective reserves but forage and migrate in the coastal marine and oceanic areas. Mobility in the form of foraging and migration takes species, such as the black petrel, sooty shearwater and godwit beyond New Zealand lands and waters further accentuates complex threat profiles. ${ }^{19}$

The example of the dotterel, thinly and widely distributed in North Island coastal habitat demonstrates the pressured state of coastal spaces and provides some explanation for why the greatest number of threatened species is found in the ranks of coastal birds. ${ }^{20}$ Coastal species (including also the godwit and the wrybill on its summer ground) are threatened by significant habitat loss and modification, and the influx of people to these areas intensifies habitat disturbance by human activity. This problem emphasises the need to better understand the limits of co-existence, as well as the benefits to both birds and humans. The enquiry now turns to the protection offered through the agreements.

\section{THE CONVENTION ON WETLANDS OF INTERNATIONAL IMPORTANCE ESPECIALLY AS WATERFOWL HABITAT (RAMSAR)}

The Convention on Wetlands of International Importance has significant potential for protecting the wetland habitat of avian species in New Zealand, but this article argues that, in New Zealand, the full potential is not realised. Directed towards wetlands at an ecosystem level, Ramsar affords protection to a broad range of wetland types. $^{21}$ Ramsar was initiated in 1971 and New Zealand became a Party in 1976. Acceding Parties are obliged to designate at least one wetland that is of international importance. In addition to the conservation of listed sites pursuant to Article 1, Ramsar creates additional obligations to promote wise use of all wetlands (Article 2), and to establish nature reserves in wetlands regardless of international importance (Article 3).

Ramsar is premised upon the concept of 'wise use' and the text recognises the interdependence of humans and the environment and underscores the value of wetlands to humans. Although explicitly positioned within the context of sustainable development, a 2005 redefinition of 'wise use' engages more overtly with ecological approaches. $^{22}$

As outlined in the Ramsar Convention Manual, the concept of 'wise use' has been further explained and associated measures to achieve the standard are recommended. Fundamental recommendations include: the preparation of a national wetland policy, the development of programmes for wetland inventory, monitoring, research and education, and the development of integrated management plans for all aspects of the wetlands and their relationships to the catchment. ${ }^{23}$ Additional Ramsar guidance

21 Ramsar Convention Secretariat, The Ramsar Convention Manual, A Guide to the Convention on Wetlands (Ramsar 1971) (Ramsar Convention Secretariat 2013) 7.

22 Ramsar Resolution IX.1 Annex D (2005), 'Ecological “outcome-oriented” Indicators for Assessing the Implementation Effectiveness of the Ramsar Convention'.

23

Ramsar Convention Secretariat 2013 (n 21) 46. 
also suggests an extensive range of integrated catchment and coastal zone measures and supports the development of regulatory measures which extend to wetland threats not routinely captured in contemporary systems. ${ }^{24}$ Ramsar was initiated before the principles of prevention and precaution were fully developed and subsequent resolutions seek to incorporate them. ${ }^{25}$ Later guidance considers that 'enshrining the principles of prevention, precaution and "the polluter pays" into decision-making on activities affecting wetlands' are key factors to enhance the effectiveness of regulation. ${ }^{26}$

\subsection{Ramsar in the New Zealand context}

Potential benefits for New Zealand wetland ecosystems arise as a result of the Convention. Ramsar raises the profile of wetlands as ecosystems under pressure and provides extensive guidance for wetland conservation and restoration. ${ }^{27}$ Site designation may also provide better protection through supporting inclusion in domestic protection schemes and increase governmental and community support. As at 2014, New Zealand has designated six wetlands. ${ }^{28}$ The progressive Arawai Kakariki programme, established by the administering agency the Department of Conservation (DOC), aims to enhance the ecological restoration of three of New Zealand's foremost wetlands, and two of the three chosen sites (Whangamarino and Awarua) are Ramsar sites. In New Zealand, the sites also gain protection from impacts from mining developments through specific inclusion within Schedule 4 of the Crown Minerals Act 1991 (as amended by section 61 of the Crown Minerals Amendment Act 2013).

Ramsar brings a focus on ecological character, vital for protecting the integrity of a site. By Article 3.2 of the Convention, Parties commit themselves to informing the Ramsar secretariat if there are changes or imminent threats to the ecological character of a designated site. ${ }^{29}$ This commitment has led to better definition and guidance $^{30}$ and the development of a framework for responding to change in wetland ecological character. ${ }^{31}$ Reporting requirements have also been instituted to ensure

24 Ramsar Convention Secretariat, Laws and Institutions: Reviewing Laws and Institutions to Promote the Conservation and Wise use of Wetlands (4th edn, Ramsar Convention Secretariat 2010) 37.

25 Ramsar (2002), 'New Guidelines for Management Planning of Ramsar Sites' Resolution VIII.14, ch VI, (2002) Guidelines on the Management and Allocation of Water' Resolution VIII.1.

26 Ramsar Convention Secretariat 2010 (n 24) 38.

27 For a full list of resolutions and recommendations see Appendix 2 of The Ramsar Convention Manual (n 21). Research suggests that waterbird abundance increases at sites following Ramsar designation: David Kleijn and others, 'Waterbirds Increase more Rapidly in Ramsar-Designated Wetlands than in Unprotected Wetlands' (2014) 51 J Appl Ecol 289.

28 Awarua Wetland with Waituna Lagoon, Farewell Spit, Whangamarino wetland, Kopuatai Peat Dome Firth of Thames and Manawatu river mouth and estuary. See Ramsar Wetlands International, Ramsar Information Sheets <http://ramsar.wetlands.org/Database/SearchforRamsarsites/tabid/765/Default. aspx $>$ accessed 20 June 2015.

29 Ramsar Convention Secretariat 2013 (n 21) 52.

30 (1996) 'Working Definitions of Ecological Character, Guidelines for Describing and Maintaining the Ecological Character of Listed Sites, and Guidelines for Operation of the Montreux Record' Resolution VI.1; Ramsar Convention Secretariat 2013 (n 21) 25.

31 Ramsar (2002), 'Assessing and Reporting the Status and Trends of Wetlands, and the Implementation of Article 3.2 of the Convention' Resolution VIII.8; Ramsar (2008), 'A Framework for processes of 
that checks are routinely made on the threats to wetland sites and changes in their condition. However, we will now see that in New Zealand's case Ramsar's reach is limited.

\subsection{The Reduced Effect of Ramsar}

Though Ramsar creates a strong foundation upon which to build wetland protection, this research establishes that protection is hindered in the New Zealand example by a lack of strong obligation at the international level and a corresponding lack of rigour in implementation at the national level. The limits of site-based protection are also demonstrated as are difficulties in obtaining integrated and consistent protection.

The value of Ramsar to shift or lessen harmful influences is weakened by its failure to adopt active precautionary and preventive language, and by its employment of the term 'wise use'. Balancing development with protection and promoting wise use 'as far as possible' is a potential contributing factor to the failure of New Zealand to effectively limit wetland degradation, and failure to achieve this balance is exacerbated by the lack of clear guidance in the implementing legislation and associated policy. $^{32}$

In addition, a persuasive 'as far as possible' approach driven by the notion of wise use dilutes potency and renders aspects of implementation more fluid. Comprehensive incorporation into domestic law is vital to implementation. The New Zealand response, although characterised by some genuine effort on behalf of the administering agencies is also marred by a range of failures, including those canvassed in subsequent paragraphs.

New Zealand has few Ramsar designated sites, only six compared with 169 in the UK, 64 in Australia and 45 in Ireland. ${ }^{33}$ In consideration of area, the six New Zealand sites, encompassing approximately 54400 ha, are dwarfed in comparison to Canada with 13066675 ha, Australia with 8117145 ha $^{34}$ and the UK with 785 361 ha. $^{35}$

Although not a matter to which the state of existing sites can be attributed, limited designation may suggest a limited enthusiasm for protection. DOC, as the responsible agency is currently in the process of establishing further criteria for prioritising Ramsar site nominations. ${ }^{36}$

A 2013 amendment to the Conservation Act 1987 has changed the manner in which Ramsar wetlands will be classified. Previously classified by the Minister of

detecting, reporting and responding to change in wetland ecological character' Resolution X.16; Ramsar Convention Secretariat 2013 (n 21) 31.

32 Controller and Auditor-General, Department of Conservation Prioritising and Partnering to Manage Biodiversity (Office of the Auditor-General 2012) 43.

33 Ramsar Convention Secretariat 2013 (n 21) 101.

34 ibid.

35 Joint Nature Conservation Committee, 'UK Ramsar Sites' (2013) < http://jncc.defra.gov.uk/page$1388>$ accessed 21 June 2015.

36 Tracie Dean-Speirs and others, Analysis of Decisions from the 10th Meeting of Contracting Parties (COP10) to the Ramsar Convention Ramsar (2011) 8; see also Ramsar (2008), 'The Ramsar Strategic Plan 2009-2015' Resolution X.1 Strategy 2.1 Ramsar site designation; Department of Conservation, National Report on the Implementation of the Ramsar Convention on Wetlands by New Zealand (Department of Conservation 2014) 41. 
Conservation by notice, section $18 \mathrm{AB}$ now provides that such decisions will be made by the Executive Council which will engage all Cabinet members in the classification. Dilution of the power of the Minister of Conservation in this manner could potentially have a chilling effect upon further Ramsar designations particularly where the areas are mineral rich or similarly suitable for exploitive purposes.

Designation of the six current sites arose through ad hoc responses to local applications and with no strategic prioritisation. A series of important shorebird sites ${ }^{37}$ currently lack Ramsar protection despite ranking highly in the recent ecosystem prioritisation exercise carried out by DOC, with several outranking designated sites. $^{38}$ Encouragement by DOC of new Ramsar site nominations that fulfil national objectives is a medium priority implementation action arising from COP10 and work is underway to achieve this. ${ }^{39}$ Designation as a Ramsar site is a common factor which triggers protective provisions in resource management plans prepared under the Resource Management Act 1991 (RMA), the legislation responsible for environmental management in New Zealand.

The effect of Ramsar is significantly reduced due to inability of site-based legal protection to extend to limiting the impacts of activities beyond the site. Using the Firth of Thames as an example, but drawing heavily on parallels from Kopuatai, Whangamarino and Waituna Lagoon, it is apparent that designated sites suffer a plight relatively similar to unprotected lands and water. At the sites, birds are exposed to a range of threats caused, inter alia, by development and activity in the catchment from sectors such agriculture and forestry. ${ }^{40}$ Many impacts stem from off site and create adverse conditions at the site. These include habitat loss and modification due to degradation of water quality, sedimentation, vegetative change, drainage, flood protection works, presence of mammalian predators and pollution. The impacts threaten the wrybill, dotterel and godwit inhabiting the Ramsar site. ${ }^{41}$

The ecosystem and habitat values protected by site designation may extend beyond the boundaries of the protected site and onto private land. ${ }^{42}$ In the case of Whangamarino, parcels of private land sit at the heart of the wetland. The boundaries of the site-based protection may fail to reflect the flow of ecological processes and the movement of species, thus creating a further vulnerability in protective effect. The Firth of Thames site is situated largely below mean high water springs and, thus, fails to incorporate much of the landward margins which species such as the wrybill, godwit and dotterel make use of. This problem is accentuated, as is the case in New Zealand, where protection is premised less upon species threat status than habitat

37 JE Dowding and SJ Moore, Habitat Networks of Indigenous Shorebirds in New Zealand (Department of Conservation 2006) 10; Woodley, personal communication (August 2013).

38 Department of Conservation, Data Layer ManagementUnits_2013Rankings_PublicViewOnly, 2013 accessed October 2013.

39 Dean-Speirs and others (n 36) 80.

40 SC Myers and others, 'Wetland Management in New Zealand: Are Current Approaches and Policies Sustaining Wetland Ecosystems in Agricultural Landscapes?' (2013) 56 Ecol Eng 107.

41 For description at Firth of Thames site see: B Brownell, J Dahm and M Graeme, Priorities and Related Actions for the Sustainable Management of the Firth of Thames Ramsar site Muddy Feet Phase II: Keep the Birds Coming (Environment Waikato Technical Report 2008/15, 2008) 14.

42 For example, Waikato Regional Council v Cookson [2009] DCR 827, CRI-2007-039-927 27 May 2009, (Kopuatai). 
protection. New Zealand lacks dedicated threatened species legislation and a statutory species listing process for designating species at risk. The Wildlife Act 1953 which ostensibly affords absolute protection to species is deficient in a number of respects including effective implementation. ${ }^{43}$ As a result protection tends to default to the RMA, the principal legislation controlling resource use, development and protection in New Zealand. By virtue of section 6(c), the focus falls upon recognising and providing for the habitats of indigenous species as a matter of national importance as opposed to species.

Generic site-based protection may also fail to recognise particular site attributes. At the Firth of Thames site, the Ramsar site designation does not recognise or spatially differentiate between particular values within that area, such as the combination of a high value foraging ground paired with an effective high tide roost. ${ }^{44}$ Identification of particular values may increase visibility and protection in domestic protection schemes.

As demonstrated through New Zealand case law, in many instances human activity and private development occur intensively on the boundaries of the Ramsar sites ${ }^{45}$ and some within these. ${ }^{46}$ The land bounding sites is commonly heavily modified by the presence of flood protection works, drainage channels and vegetation clearance, stock grazing and other farming activities. Failure to control adjacent land uses impacts habitat quality and causes species disturbance. ${ }^{47}$ Buffer zones to protect sites are not in evident use, as is recommended in Ramsar guidance and in contemporary legislative schemes. ${ }^{48}$ Case law demonstrates problems with clear demarcation of the sites, the need for interpretation on the actual sites, education of landowners in proximity to the site and within the catchment, and the value that establishment of protective buffer zones would have in reducing the impacts from adjoining activities. ${ }^{49}$ At the Firth of Thames site it is evident that illegal grazing, reclamation and vehicle use has been occurring within the boundaries of the site for many years. ${ }^{50}$ The activities have occurred despite being within a sensitive area where livestock presence is a prohibited activity and vehicle use discretionary requiring resource consent under the Regional Coastal Plan. ${ }^{51}$ Furthermore, although the terrestrial related Regional Plan applies priority stock exclusion rules to a number of

Wallace (n 4) conclusions.

Keith Woodley, Shorebirds of New Zealand; Sharing the Margins (Penguin Books (NZ) Ltd 2012) 231.

For example: Waikato Regional Council v Cookson (n 42); Southland Regional Council v Belling DC Invercargill CRI-2010-025-004368, CRI-2010-025-004366 10 June 2011 (Awarua/Waituna); and Southland Regional Council v Pantas Corporation DC Invercargill CRI-2007-025-3342 (Awarua/Waituna).

6 For instance, the grazing of stock, reclamation, drainage works, vehicle access and rubbish disposal, see for example Waikato Regional Council Abatement Notice issued to Flint Farms Ltd pursuant to s 324 RMA 16 August 2013 DOC\#2800980.

Brownell, Dahm and Graeme (n 41).

Ramsar Resolution VIII.14, ch VI, (n 25) Annex, X; Barbara Lausche and others, The Legal Aspects of Connectivity Conservation: A Concept Paper (IUCN 2013) 92.

9 For example, Waikato Regional Council v Cookson (activities bounding Kopuatai) (n 42), Southland Regional Council v Belling (discharge in proximity to Awarua/Waituna) (n 45) and Waikato Regional Council v Tuitahi Farms Ltd DC Auckland CRI-2014-075-000155 3 July 2014 (discharge in proximity to Firth of Thames).

Waikato Regional Council 2013 (abatement notice) (n 46).

Waikato Regional Council, Regional Coastal Plan (Waikato Regional Council 2005). rr 16.2.9 and 16.6.3. 
priority water courses entering the site, the coverage is not entirely comprehensive and the area is lacking supporting buffer zones. ${ }^{52}$ Effective land use planning which includes neighbouring areas within protective mechanisms is clearly lacking in the New Zealand example. In conjunction with a recommendation for implementation of Ramsar site buffer zones in New Zealand, a more nuanced approach to spatial zoning of the site and surrounding areas would also be beneficial. ${ }^{53}$

Deterioration in ecological character and the ongoing impact of illegal activities also suggest a failure to follow the extensive Ramsar guidance prepared to assess and monitor sites, as well as sufficiently applying guidance as to ecological outcome indicators to assess the implementation effectiveness of the Convention. ${ }^{54}$ Furthermore, New Zealand is insufficiently describing and reporting changes to ecological character, and resultant management responses, as required by the Convention. ${ }^{55}$ There is a need to assess the adequacy of monitoring currently being conducted at the sites, and for updated information sheets (RIS) to be filed for the respective sites. ${ }^{56}$

These are largely matters that may also be the subject of a management plan, which can define the characteristics of a site, identify the pressures, develop responses, allocate roles and assess funding needs and arrangements. Such plans are recognised in the Ramsar Convention guidance as fundamental to achieving 'wise use' and are intended to be integrated into the public development planning system at local, regional or national level. ${ }^{57}$ The Ramsar Convention does not, however, require their preparation. Consequently, the Manawatu Ramsar site is the only one in New Zealand to have a current dedicated management plan, although more coarsely framed provisions within the Waikato Conservancy Management Strategy are adopted as management plans in the 2014 report back on the Convention. ${ }^{58}$ Important opportunities are lost to put into force a Ramsar Convention resolution that recognises 'that site-based management planning should be one element of a multi-scalar approach to wise use planning and management and should be linked with broad-scale landscape and ecosystem planning ...59

Insufficient comprehensive management planning has knock-on effects for the day-to-day management of sites (including pest management) because of precarious funding situations. At the Firth of Thames site, this task largely falls to the Miranda

52 Waikato Regional Council, Waikato Regional Plan (Waikato Regional Council 2007) r 4.3.5.4 and Waikato Regional Plan Priority Catchments for Stock Exclusion - GIS Layer, the spatial data representing Priority Catchments for Stock, Exclusion Data was derived by Waikato Regional Council from LINZ and NIWA/MFE data access date October 2013.

53 Zeng recommends the adoption (and enhancement) by Ramsar of the UNESCO-MAB Biosphere Reserve zonation system to enable greater utility and flexibility Qing Zeng and others, 'Perspectives on Zonation in Ramsar Sites, and Other Protected Areas: Making Sense of the Tower of Babel' (2014) 4 Open J Ecol 788.

54 Ramsar (2005), 'An Integrated Framework for Wetland Inventory, Assessment and Monitoring' Resolution IX.1 Annex E; Ramsar (2005) 'Ecological “outcome-oriented” Indicators for Assessing the Implementation Effectiveness of the Ramsar Convention' Resolution IX.1 Annex D.

55 Department of Conservation 2014 (n 36) 46.

56 art 3.2, Ramsar (2008) 'The status of sites in the Ramsar List of Wetlands of International Importance' Resolution X.13, 18, 19 and Annex 1; Dean-Speirs and others (n 36) 24.

57 Resolution VIII.14, ch VI, (n 25) Annex, 19.

58 Department of Conservation 2014 (n 36) 43.

59 Resolution VIII.14, ch VI (n 25) Annex, 20. 
Naturalists' Trust, a non-governmental organisation (NGO) which runs the Shorebird Centre adjacent to the site.

As part of its Natural Heritage Management System, DOC has developed new tools to optimise the management of threatened species and to prioritise the management of ecosystems by grouping them into 'Ecosystem Management Units' ${ }^{60}$ In terms of ranking, a 2013 geographical information system (GIS) dataset indicates ${ }^{61}$ that Kopuatai, Farewell Spit and Manawatu are Ramsar sites that will receive priority within the next four years. The presence of threatened species at these sites may in time act as an additional ground for prioritisation. Currently, however, the rankings demonstrate that designation as a site of international importance may not be particularly important in setting management priorities.

Although the 2014 National Report on the Implementation of the Ramsar Convention on Wetlands by New Zealand records 'Taken in their entirety, the ecological character of New Zealand's Ramsar sites has not changed significantly since the last report', it is clear that degradation at sites continues largely attributable to resource use and development within catchments. ${ }^{62}$ Significant concern exists relating to high anthropogenic nitrogen loads stemming from agricultural activity in the catchments. Consequent ocean acidification of the Firth of Thames, particularly from the Waihou and Piako Rivers which discharge into the Ramsar site is an accelerating problem. ${ }^{63}$

The situation at Waituna Lagoon is so serious that scientists warn of the real risk of a catastrophic change in state, due to the excessive nutrient loads ${ }^{64}$ exacerbated by a significant rate of conversion to dairy farming in the southland Region. DOC's 2012 National Report on the Implementation of the Ramsar Convention on Wetlands by New Zealand described these potential threats to ecological character as 'an emerging challenge'. 65

Policy and regulatory failure to limit ecological damage to wetland ecosystems in New Zealand's agricultural landscapes documented by Myers and others, noted a failure to meet Ramsar objectives to prevent further wetland loss. ${ }^{66}$ In addition, rules in implementing plans were uneven in strength: less than half had strong regulation and monitoring, hence implementation was sparse. ${ }^{67}$ Myers documents ongoing loss of wetlands and makes a number of recommendations including integrating and strengthening national legislation and policy direction, preparation of strong national

60 John Leathwick, Elaine Wright and Andy Cox, Prioritisation of Ecosystem Management (Department of Conservation 2012); John Leathwick and Elaine Wright, Integrated Prioritisation of Ecosystems and Species (Department of Conservation 2012).

61 Department of Conservation, Data Layer Management Units_PublicViewOnly_Extract7Aug2013, 2013.

62 Department of Conservation (n 36) 49.

63 John Zeldis, 'Linking Ocean Acidification, Eutrophication, and Land Use' in TL Capson and J Guinotte (eds), Future Proofing New Zealand's Shellfish Aquaculture: Monitoring and Adaptation to Ocean Acidification: New Zealand Aquatic Environment and Biodiversity Report No 136, (Ministry for Primary Industries 2014) 32; Hauraki Gulf Forum, State of the Gulf (Hauraki Gulf Forum 2014) 12.

64 Peter Scanes, Nutrient Loads to Protect Environmental Values in Waituna Lagoon, Southland NZ (Environment Southland 2012) 1.

65 Department of Conservation, National Report on the Implementation of the Ramsar Convention on Wetlands by New Zealand (Department of Conservation 2012) 9.

66 Myers and others (n 40) 107.

67 ibid. 
policy statements which direct bottom lines for protecting wetlands, and stronger rules in regional and district plans to protect wetlands coupled with more effective monitoring and enforcement. ${ }^{68}$

An amended National Policy Statement for Freshwater Management 2014 has since been introduced. ${ }^{69}$ This is intended to strengthen protection of freshwater and include provision for 'bottom lines' for ecosystem health. While widely recognised as a necessary initiative, ${ }^{70}$ early concerns have been expressed including: the failure to establish a framework for managing wetlands; the need for biological indicators which reflect the cumulative effects of multiple stressors; and bottom lines associated with more integrative measures of ecosystem health, such as fish and insect populations. $^{71}$ The gap surrounding policy for wetland management is deepened by the failure of New Zealand to revise the outdated National Wetland Policy 1986 to reflect the extensive Ramsar guidance material.

The example of the Firth of Thames, at the interface of land and water and the public and private domains, draws into sharp focus the amalgam of agency responsibility for the site and associated values, a problem replicated at other Ramsar sites. Implementation of Ramsar is the responsibility of DOC, as is species management at the site, pursuant to the Wildlife Act 1953 and the Conservation Act 1987. Yet a large proportion of the site lies within the coastal marine area, administered by the Regional Council. Integrated management of the catchment is the responsibility of the Regional Council which is also responsible for flood control in the catchment, creating a dual role and, at times, conflicting objectives pertaining to preserving biodiversity and managing flood waters.

In terms of land use, the site is dissected and two separate District Councils control land bordering the site. In addition, the Hauraki Gulf Marine Park Act 2000 provides for special recognition of the area, and the Hauraki Gulf Forum is tasked with managing the gulf and its catchments. The multiple responsibilities and divisions create silos and limit opportunity for strategic conservation planning, particularly across the public and private estates. In particular, what is missing is strategic planning for 'threatened' and 'at risk' species driven by the needs of the species as opposed to the silos of the plans and administering agencies. ${ }^{72}$ A recent analysis of implementation of Ramsar notes both the need to refine administrative arrangement to implement it and to improve the level of coordination among wetland managers, government agencies and

68 ibid 117.

69 Ministry for the Environment, Proposed Amendments to the National Policy Statement for Freshwater Management 2011: A Discussion Document (Ministry for the Environment 2013).

70 And recommended by the Land and Water Forum 2012: Land and Water Forum, Report of the Land and Water Forum: A Fresh Start for Fresh Water (2010); Land and Water Forum, Second Report of the Land and Water Forum: Setting Limits for Water Quality and Quantity, and Freshwater Policy - and Plan-Making Through Collaboration (2012).

71 New Zealand Freshwater Sciences Society, 'Media Statement from the New Zealand Freshwater Sciences Society: Response to the Proposed Amendments to the National Policy Statement for Freshwater Management' 2013 and Science Media Centre, 'Freshwater National Standards set - Experts Respond' <http://www.sciencemediacentre.co.nz/2014/07/03/freshwater-national-standards-set-experts-respond $>$ accessed 21 June 2015.

72 Wallace (n 4) 442. 
stakeholders. $^{73}$ Greater interaction between DOC and Regional councils at the strategic level would benefit the protection of threatened species. The lack of national direction in the form of a national wetlands policy, or national Wetlands Action Plan also limits an effective shared responsibility approach. ${ }^{74}$

\subsection{Ramsar Summary}

The Ramsar Convention could be more effectively implemented in New Zealand. There is a clear need to designate further important sites, prepare a National Wetlands Plan, make effective management plans for existing sites, obtain secure funding for site management and develop buffer zone systems to better protect site values. These are pressing issues, yet the greatest problem is the failure to adequately manage factors external to the Ramsar sites, such as farming and water quality loss. Ecological character of the key sites continues to degrade, and the failure to effectively address the underlying causes of this loss evidences a lack of commitment on the part of New Zealand. Significantly more could be made of this Convention to benefit birds in New Zealand, through greater engagement, implementation and integration across the landscape. Having identified that the Ramsar approach is weakened by these factors attention now turns to the impact of the CBD.

\section{THE CBD}

Similar to Ramsar, the $\mathrm{CBD}^{75}$ has considerable potential for delivering benefits to the case study species. As a framework convention, it provides significant guidance and leadership in developing a global approach to the conservation of biodiversity. The CBD measures are extensive and directed at critical problems to achieve the reduction of biodiversity decline.

\subsection{The Reduced Effect of the CBD}

Despite this positive direction, the targets set pursuant to CBD have not been met globally. ${ }^{76}$ This article argues that a lack of strong obligation at the convention level hampers the effect of the convention and is compounded by insufficient implementation at the national level. As a means of strengthening the obligation upon nation states and improving the status of the case study birds the Aichi targets are investigated, but again, problems are identified with reduced effect due to limits on obligation and potential flow-on effects in implementation. At the implementing national level a need to address the underlying causes of biodiversity loss is identified, as well as a need to more effectively regulate damaging industry practices.

CBD obligations are cast on a more general level enabling a degree of autonomy and allowing for varying capacity of implementing nations. ${ }^{77}$ The near-universal

73 Controller and Auditor-General, Report of the Controller and Auditor-General, Tumuaki o te Mana Arotake: Meeting International Environmental Obligations (Audit Office 2001) 58; Dean-Speirs and others (n 36) 6; Controller and Auditor-General 2012 (n 32) 42.

74 Controller and Auditor-General (n 73) 57.

75 The 1992 Convention on Biological Diversity. 1760 UNTS 79 (1992), art 8.

76 United Nations Environment Programme, GEO5 Global Environment Outlook: Environment for the Future we Want (UNEP 2012) 83.

77 Harrop (n 1) 119-20. 
participation in the $\mathrm{CBD}$, and the compromises inherent in such an approach, limit the effectiveness of the Convention. The words used are general and enabling as opposed to applying any strong prescriptive obligation. Cast as loose obligations such as 'to promote' protection, rehabilitation or recovery, or to 'regulate' or 'manage' processes and activities, the wording gives no real indication of the strength or intended efficacy of the measures exhorted. ${ }^{78}$ The lack of direction pertaining to degree of obligation leaves the choice about the level of protection open to the implementing organisation.

Where the causes of loss are known (as many are) a loose obligation must limit response with respect to actively protecting species. Moreover, the CBD is limiting in the extent to which it utilises the principles of precaution, prevention and avoidance, which influences the extent of obligation upon contracting parties. The CBD does little to support a strong, active precautionary approach to the loss of threatened species. Although noting the precautionary principle in its preamble, the CBD applies a weak and non-active version which seeks to prevent lack of full scientific certainty being used as a reason to postpone measures to avoid or minimize a threat of significant reduction or loss of biodiversity. No binding articles drive precautionary action. As the CBD has developed, the precautionary principle has been applied in a range of additional decisions including marine and coastal biodiversity, ${ }^{79}$ invasive alien species, ${ }^{80}$ the ecosystem approach ${ }^{81}$ and guidelines on sustainable use. ${ }^{82}$

Similarly, no principle of prevention figures strongly in the CBD. The Preamble identifies the critical need to 'anticipate, prevent and attack the causes of significant reduction or loss of biodiversity at source'. However, the prevention of harm to species is a goal that is not explicitly stated in the Articles. The obligations tend to extend to the regulation and management of activities, although Article 10(b) requires Parties to '[a]dopt measures relating to the use of biological resources to avoid or minimize adverse impact on biological diversity'.

New Zealand's two most recent reports on meeting the CBD obligations record mixed results, with clear under-performance regarding species protection including failing to achieve the global targets related to threatened species status and, in terms of the trends in abundance and distribution of selected species. ${ }^{83}$ Of the case study species, the kokako alone has seen an upward trend in conservation status, although the bird remains conservation dependent. Failure to adequately control predators, habitat loss and modification, and fisheries bycatch continue to limit the case study species. It is recognised that considerable difficulty exists in managing and protecting

78 For example arts 8 (d) and (f).

79 CBD (1995), 'Conservation and Sustainable use of Marine and Coastal Biological Diversity' Decision II.10, SBSTTA I.8.

80 CBD (2002), 'Alien Species that Threaten Ecosystems, Habitats or Species' Annex, Decision VI.23 and CBD (2000), 'Alien Species that Threaten Ecosystems, Habitats or Species' Decision V.8.

81 CBD (2000), 'Ecosystem Approach’ Decision V.6.

82 CBD (2004), 'Sustainable Use' Decision VII.12.

83 New Zealand Government, New Zealand's Fourth National Report to the United Nations Convention on Biological Diversity (2010), 57-58, <http: //www.cbd.int/doc/world/nz/nz-nr-04-en.pdf > accessed 20 June 2015; New Zealand Government, New Zealand's Fifth National Report to the United Nations Convention on Biological Diversity (2014) 9, <http://www.cbd.int/doc/world/nz/nz-nr-05-en.pdf $>$ accessed 21 June 2015. 
species on the public conservation estate (approximately one-third of New Zealand land area), with the size of the task of conserving species being beyond the scope of the resources allocated. ${ }^{84}$ This problem is accentuated on private land where although species continue to be 'owned' by the Crown any concomitant protection and management effort is reduced. Technically, species are afforded 'absolute protection' by the Wildlife Act 1953, yet elsewhere I have identified significant limitations in protection, and implementation deficiencies. ${ }^{85}$ Particular issues arise in relation to resource use and development and permitting for incidental loss. In addition, the Ramsar examples canvassed above demonstrate New Zealand's failure to adequately capture and control the externalities of resource use and development, and section 5 will discuss similar problems arising from incidental fisheries mortality.

The CBD provides New Zealand with a clear mandate to apply an ecosystems approach. Yet, the problems identified in the Firth of Thames site, suggest that there are limitations to achieving a holistic approach in protecting ecological integrity and to securing an ecosystems approach in conjunction with 'wise use'. Bringing this problem back to the parent Conventions is illuminating. Despite some significant attempts at integrating the $\mathrm{CBD}$ and Ramsar, recent commentators note that that there is 'remarkably little linkage on common issues across the two programmes' ${ }^{86}$ A failure to achieve cross-sectoral and integrated approaches in landscape and seascapes runs counter to the overarching ecosystem approach.

To resolve the deepening biodiversity crisis, and strengthen approaches to sustainable use, the 10th meeting of the Conference of Parties to the CBD identified an updated set of targets (the Aichi biodiversity targets) and approved a revised strategic plan for biodiversity, for the 2011-20 period. ${ }^{87}$ Parties are obliged to translate this strategic plan into national biodiversity strategy and action plans prepared pursuant to Article 6 of the CBD. Responses to previous targets ${ }^{88}$ were recognised as being inadequate due to an insufficient scale upon which to address the pressures and insufficient integration of biodiversity issues into broader policies, strategies, programmes and actions to enable the underlying drivers to be adequately addressed. ${ }^{89}$ Lack of financial, human and technical resources were also identified as limiting implementation of the convention. ${ }^{90}$ These are problems which, not unexpectedly, are also identified in relation to Ramsar. The Aichi targets are introduced to address these problems and raise the bar for biodiversity protection. Achievement of the targets would significantly improve the outlook for the six case study birds, as they more rigorously address threats to the birds.

Controller and Auditor-General (n 32) 10; Liana Joseph and others, 'Improving Methods for Allocating Resources Among Threatened Species: The Case for a New National Approach in New Zealand' (2008) 14 Pacific Conserv Biol 154, 155.

85 Wallace (n 4) s 7.3.3.

86 Nick Davidson and David Coates, 'The Ramsar Convention and Synergies for Operationalizing the Convention on Biological Diversity's Ecosystem Approach for Wetland Conservation and Wise Use' (2011) 14 J Int Wildlife L Policy 204.

87 CBD (2010), 'Strategic Plan for Biodiversity 2011-2020' Decision X.2.

88 Specifically the 2010 biodiversity target, see Decision X.2 (n 91) cl (I) (7).

89 See n $87, \mathrm{cl}(\mathrm{I})(5)$.

90 CBD Decision X.2 (n 87) cl (I)(5) \& (6). 
The Aichi targets are stronger and more directive as to the obligation cast than the parent Convention. Yet they remain aspirational and flexible, reliant upon the establishment of national or regional targets for their implementation. ${ }^{91}$ Given the New Zealand Ramsar response, the lack of binding legal obligation raises an immediate concern. It is currently unclear how New Zealand intends to proceed on this issue, as a revised National Biodiversity Strategy is yet to be released.

Target 12 suggests immediate gain by 2020 for the dotterel, black petrel and wrybill as it provides 'By 2020 the extinction of known threatened species has been prevented and their conservation status, particularly of those most in decline, has been improved and sustained'. ${ }^{92}$ However, it is tempered by 'particularly of those most in decline', which may provide justification to contracting parties to prioritise the critical as opposed to the vulnerable. This may not provide sufficient momentum and response for species such as the black petrel or dotterel.

Target 5 includes the requirement that the rate of loss of all natural habitats, including forests, be at least halved by 2020 and 'where feasible' brought close to zero with an emphasis upon preventing the loss of high-biodiversity value habitats, such as forests and wetlands. ${ }^{93}$ The technical rationale for the target defines loss to include degradation and fragmentation. ${ }^{94}$ In the New Zealand example, this is particularly important as a significant issue now is not so much the loss of primary forests, rather the need for intensive pest management. Other insidious forms of damage and incidental loss threaten each of the study species. The New Zealand dotterel habitat is threatened by the extension of coastal development and associated disturbance, the wrybill, likewise through the loss of aerial, coastal and riverine habitat. ${ }^{95}$ This form of loss occurs on an incremental basis and builds cumulative effects over time. ${ }^{96}$

Two clear limitations stem from Target 5. The first is the lack of full ability to measure the rate and extent of habitat loss and the second is the use of the exceptional words 'where feasible'. While the area of land and wetland incrementally lost can be measured, loss arising from the introduction to the area of human activity and associated cargo such as machines, infrastructure and pets is not so readily captured, and accordingly less readily stemmed. Although the monitoring of bird species has a higher profile relative to other species, the task is constrained by various factors including scarcity, difficulty of terrain, nocturnal habits, small population size and extent of conservation funding and priority. ${ }^{97}$ This is problematic as it is not possible to measure the loss of something that is not known to exist. Policy directed at habitat loss and threats to species needs to be underpinned by stronger evidence of the consequences of human activity on species to improve prospects for co-existence.

91 CBD Decision X.2 (n 87) (IV) (13). For discussion on the failure of the CBD to apply binding legal obligations as opposed to targets see Harrop and Pritchard (n 1) 474.

92 CBD Decision X.2 (n 87) cl (IV) (13) Strategic Goal C, Target 12.

93 CBD Decision X.2 (n 87) Annex, IV.

94 CBD Decision X.2 (n 87) Technical Rationale COP/10/27/Add.1.

95 Wallace (n 4) ch 4; Woodley (n 44) 178, 191.

96 Woodley (n 44) 178, 191.

97 William Lee, Matt McGlone and Elaine Wright, Biodiversity Inventory and Monitoring: A Review of National and International Systems and a Proposed Framework for Future Biodiversity Monitoring by the Department of Conservation (Landcare Research Contract Report LC0405/122 (unpublished) 2005) 41, 48. 
As well as habitat loss, the Aichi targets address specific sectoral damage and modification to the environment. Target 6 requires that 'fisheries have no significant adverse impacts on threatened species and vulnerable ecosystems and the impacts of fisheries on stocks, species and ecosystems are within safe ecological limits' ${ }^{98}$ Elsewhere I have concluded that dismantling a legislative sectoral defence, ${ }^{99}$ implementation of marine spatial zoning controls and additional mitigation measures are required in order to secure this target in the case of the black petrel. ${ }^{100}$ Target 8 requires that: 'By 2020, pollution, including from excess nutrients, has been brought to levels that are not detrimental to ecosystem function and biodiversity. ${ }^{101}$ This target produces benefits to all case study species, but it would particularly counter the damage currently suffered by wetland and marine species. The example of the Firth of Thames indicates that significant additional controls upon agricultural discharge would be required in order to abate the current extensive nutrient pollution.

Target 9 deals with invasive alien predators and directs that: 'By 2020, invasive alien species and pathways are identified and prioritized, priority species are controlled or eradicated, and measures are in place to manage pathways to prevent their introduction and establishment. ${ }^{, 102}$ This strengthens the original obligation contained in Article $8(\mathrm{~h})$ of the CBD and is supported by a programme of work and guiding principles. ${ }^{103}$ The key determinant for benefit to the case study species in implementing this target will be the interpretation of 'priority species' and the level of eradication and control applied. Due to the pressures of alien invasive species, it is projected that: 'few of the current indigenous New Zealand forest birds will persist on the mainland without predator control on a vastly larger scale than currently undertaken. $^{\text {,104 }}$

Guiding principle 13 (Eradication) provides 'Where it is feasible, eradication is often the best course of action to deal with the introduction and establishment of invasive alien species. ${ }^{105}$ When eradication is not feasible, principle 15 supports control measures that focus on reducing the damage caused as well as reducing the number of the invasive alien species. A stronger and more effective obligation would

CBD Decision X.2 (n 87) cl (IV) (13) Strategic Goal B, Target 6.

Where the incidental loss arises as part of a fishing operation, s $68 \mathrm{~B}(4)(\mathrm{b})$ of the Wildlife Act 1953 operates as a defence provided all necessary reporting requirements were fulfilled.

Wallace (n 4) conclusions.

CBD Decision X.2 (n 87) cl (IV) (13) Strategic Goal B, Target 8.

CBD Decision X.2 (n 87) cl (IV) (13) Strategic Goal B, Target 9.

CBD Decision VI.23 (n 80) Annex, Principles 1-3; CBD (1998), 'Report and Recommendations of the Third Meeting of the Subsidiary Body on Scientific, Technical and Technological Advice, and Instructions by the Conference of the Parties to the Subsidiary Body on Scientific, Technical and Technological Advice' Decision IV.1 C; CBD (2000), 'Alien Species that Threaten Ecosystems, Habitats or Species' Decision V.8; CBD (2002), 'Alien Species that Threaten Ecosystems, Habitats or Species' Decision VII.13; CBD (2006), 'Alien Species that Threaten Ecosystems, Habitats or Species (Article 8 $(\mathrm{H})$ ): Further Consideration of Gaps and Inconsistencies in the International Regulatory Framework' Decision VIII.27; CBD (2008), 'In-Depth Review Of Ongoing Work on Alien Species that Threaten Ecosystems, Habitats or Species' Decision IX.4; CBD (2010), 'Invasive Alien Species' Decision X.38; CBD (2012), 'Invasive Alien Species' Decision XI.28.

04 John Innes and others, 'Predation and Other Factors Currently Limiting New Zealand Forest Birds' (2010) 34 New Zeal J Ecol 86, 105.

CBD Decision VI.23 (n 80) Annex. 
assert a requirement for the control of alien species to levels compatible with increasing populations and range of threatened species, and to prevent additional species being classed as 'threatened'.

The New Zealand response pursuant to the Biosecurity Act 1993 as amended by the Biosecurity Law Reform Act 2012, and associated pest management strategies and plans, is not directed at full eradication. Obligations imposed upon private land owners and the Crown are tentative in recognition of the scale of the problem and the economic cost. The imposition of good neighbour rules ${ }^{106}$ to manage pests that cause external costs to other land holders is in principle a progressive move, although the extent of the obligation on landowners is less clear due to the desire to balance property rights and obligations. ${ }^{107}$

\subsection{CBD Summary}

Despite extensive guidance in principle, weak directive obligations inhibit the force of the CBD. Nevertheless, a significant impact of the CBD arises from the binding obligation upon Parties to produce national biodiversity strategies and action plans. ${ }^{108}$ This produces a strong national focus regarding implementation of the CBD. New Zealand is overdue in its obligation to file a reviewed national biodiversity strategy and action plans, and its most recently released national report provides little confidence that the Aichi targets related to 'threatened' species will be met. ${ }^{109}$ A more active and stringent approach to protecting 'threatened' species in New Zealand is called for. The examination now turns to the final Convention and the protection of migratory species.

\section{CONVENTION ON THE CONSERVATION OF MIGRATORY SPECIES OF WILD ANIMALS}

Protecting endangered migratory species is the focus of the Convention on the Conservation of Migratory Species of Wild Animals (CMS), which came into force in 2000. ${ }^{110}$ The CMS enables States to work together to protect migratory routes that extend beyond a nation's borders. With regard to the case study species, the black petrel, sooty shearwater and the bar-tailed godwit qualify as migratory species, ${ }^{111}$ although none are sufficiently endangered to warrant high-grade protection of Appendix I.

The most critical feature of CMS for the case study species lies in its structure which provides for binding obligations through the development of subsidiary agreements, and the development of action plans and memoranda of understanding. This is critical in view of species-specific threats, for example, the impact of bycatch to the

106 s 2(1) Biosecurity Act 1993.

107 For further discussion see Wallace (n 4) s 8.4.

108 art 6.

109 New Zealand Government 2014 (n 83).

110 The 1979 Convention on the Conservation of Migratory Species. 1651 UNTS 333 (1980).

111 art 1 of the CMS defines migratory species as the entire population or any geographically separate part of the population of any species or lower taxon of wild animals, a significant proportion of whose members cyclically and predictably cross one or more national jurisdictional boundaries. 
black petrel ${ }^{112}$ which could be improved by specific adjustments, such as the manner in which a fishing line is weighted, or the time that it is cast. ${ }^{113}$

The CMS has 120 Parties and covers 573 species in Appendices I and II. Consequently, individually crafted responses tuned to spatial and temporal needs will be required for many species. While CMS indicates that this is the responsibility of the implementing nations, CMS's structure enables some direction to be given at the international level, thus creating species-specific obligations on a wider level. ${ }^{14}$ As will be examined, a sharpened focus potentially delivers greater benefits for those species within this frame, yet may also cause a degree of uneven treatment for those species without.

The CMS enables a stepped approach to species protection, providing the strongest protection for endangered species listed in Appendix I, but using Appendix II to enable the provision of binding agreements for those species considered to have unfavourable conservation status as defined by Article I. ${ }^{115}$

Classification as an endangered species entails that the species be in danger of extinction throughout all or a significant portion of its range.' ${ }^{116}$ The black petrel's vulnerable status is insufficient for Appendix I classification, yet a lesser form of protection is extended via classification in Appendix II, due to its 'unfavourable conservation status. ${ }^{117}$ An Appendix II listing is also available where the conservation status of a species would significantly benefit from the international cooperation that could be achieved through an international agreement, ${ }^{118}$ and the bar-tailed godwit not classified as 'threatened' in New Zealand, receives Appendix II status, which is extended to the entire scolopacidae family. In contrast, the sooty shearwater is unlisted.

\subsection{The CMS Approach}

Article II of the CMS confirms the fundamental principle to conserve migratory species and their habitats, whenever possible and appropriate, and includes acknowledgment by the Parties of 'the need to take action to avoid any migratory species becoming endangered'. Parties should promote research, provide immediate protection for Appendix I species and endeavour to conclude agreements for the conservation and management of species listed in Appendix II. ${ }^{119}$

112 Yvan Richard and Edward Abraham, Risk of Commercial Fisheries to New Zealand Seabird Populations, 2006-07 to 2010-11 (New Zealand Aquatic Environment and Biodiversity Report No 109 2013) 23.

113 Karen Baird and Biz Bell, Bycatch of Black Petrel in New Zealand Fisheries (Fifth Meeting of the Seabird Bycatch Working Group, Agreement for the Conservation of Albatrosses and Petrel, SBWG5 Doc 37 Agenda Item 10 2013) 6.

114 Richard Caddell, 'International Law and the Protection of Migratory Wildlife: An Appraisal of Twentyfive years of the Bonn Convention' (2005) 16 Colo J Int Environ L Poly 113, 122 and 126.

115 ibid 128; John Cooper and others, 'The Agreement on the Conservation of Albatrosses and Petrels: Rationale, History, Progress and The Way Forward' (2006) 34 Mar Ornithol 1-5.

116 art I (1) (e).

117 The black petrel was added to Appendix II through amendment via COP6, Secretariat of the Convention on Migratory Species 'Annotated Appendices to the Convention' < http://www.cms.int/ documents/appendix/additions_table1.pdf $>$ accessed 20 June 2015.

118 art IV (1).

119 art II (2) and (3) (a), (b) and (c). 
Article III of the CMS, providing for the listing in Appendix I of endangered species, creates measures which states within the range of the species (Range States) must implement to protect the species. ${ }^{120}$ The CMS also prohibits taking of the endangered species, excepting a limited range of conditions. ${ }^{121}$

The CMS creates relatively strong obligations, but is tempered by words and phrases such as 'whenever possible and appropriate', 'promote', 'endeavour', 'to the extent feasible and appropriate' which are open to interpretation. ${ }^{122}$ Moreover, enabling minimisation as an alternative to avoidance, regarding activities that seriously impact migration, reduces the strength of any obligation. The restrictions listed in Article III apply to Appendix I species and do not benefit the case study species in this research. The CMS applies neither the precautionary nor the preventive principle. The scope and intent of the CMS has expanded and been augmented by a series of resolutions, which incorporate an ecosystem approach and simultaneously seek to address a range of issues threatening migratory species, including the significant impact of fisheries bycatch. ${ }^{123}$

Recently, CMS's Draft Strategic Plan 2015-2023 ${ }^{124}$ adopts the CBD Aichi Targets, which drives a heightened intention to deliver, in principle, comprehensive protection on a range of fronts. Decision X.20 of the Conference of the Parties to the $\mathrm{CBD}$ recognises CMS as the lead partner in the conservation and sustainable use of migratory species over their entire range and the Draft Strategic Plan incorporates this partnership approach. ${ }^{125}$

If the targets proposed in the CMS's Draft Strategic Plan 2015-2023 are comprehensively implemented they offer considerable protection. The targets are broad and include mainstreaming of awareness of values of migratory species and

C CMS (2002), 'Impact Assessment and Migratory Species' Resolution VII.2; CMS (2002), 'Oil Pollution and Migratory Species' Resolution VII.3; CMS (2002), 'Electrocution of Migratory Birds' Resolution VII.4; CMS (2002), 'Wind Turbines and Migratory Species' Resolution VII.5; CMS (2002), 'Implications for CMS of the World Summit on Sustainable Development Resolution' VII.10; CMS (2005), Climate Change and Migratory Species Resolution VIII.13; CMS (2005), 'Bycatch' Resolution VIII.14; CMS (2005), 'Migratory Species and Highly Pathogenic Avian Influenza' Resolution 8.27; CMS (2008), 'Bycatch' Decision IX.18; CMS (2008), 'Climate Change Impacts on Migratory Species' Resolution IX.7; CMS (2008), Responding to the Challenge of emerging and re-emerging diseases in Migratory Species, including Highly Pathogenic Avian Influenza H5. Resolution IX.8; CMS (2011), 'The Role of Ecological Networks in the Conservation of Migratory Species' Decision X.3; CMS (2011), Guidance on Global Flyway Conservation and Options for Policy Arrangements Resolution X.10; CMS (2011), 'Power Lines and Migratory Birds' Decision X.11; CMS (2011), 'Guidelines on the Integration of Migratory Species into National Biodiversity Strategies and Action Plans (NBSAPs) and Other Outcomes from CBD COP10' Resolution X.18; CMS (2011), 'Migratory Species Conservation in the Light of Climate Change' Resolution X.19; CMS (2011), 'Minimizing the Risk of Poisoning to Migratory Birds' Resolution X.26.

124 CMS Inter-sessional Strategic Plan Working Group, The Strategic Plan for Migratory Species 2015-2023 Draft Skeleton for Consultation (UNEP, CMS 2013) 3.

125 CMS (2010), 'Cooperation with Other Conventions and International Organizations and Initiatives' Decision X.20, cl 13 recalling Decision VI.20, CMS Working Group 2013, ibid 1. 
conservation, ${ }^{126}$ elimination or reform of harmful incentives and development of incentives to conserve, ${ }^{127}$ protection of all sites defined as being of critical importance for migratory species by 2020, ${ }^{128}$ measures developed to minimise genetic erosion, ${ }^{129}$ inclusion of priorities for conservation and management of migratory species in national biodiversity plans and strategies, ${ }^{130}$ adoption of traditional knowledge and knowledge improvements ${ }^{131}$ and mobilisation of resources. ${ }^{132}$ Other more specific targets relating to safe ecological limits, ${ }^{133}$ protection of key areas, ${ }^{134}$ elimination of significant adverse effects from fisheries, ${ }^{135}$ substantial reduction of multiple anthropogenic pressures ${ }^{136}$ and considerable improvement to the status of threatened migratory species ${ }^{137}$ offer considerable potential protection for the case study species. Achieving these targets would effectively eliminate most of the main pressures on the case study species.

Success will be measured through implementation. In consideration of the threats posed to the black petrel and the sooty shearwater, there is a considerable gap between the current position of the birds and the targets proposed. The greatest benefit from the CMS for the case study species derives from the focus on migratory species and acknowledgment of the need to avoid endangering such species. More direct protection, however, is left to the action of Appendix II agreements or more general Memoranda of Understanding. The next section considers the impact of those agreements.

The CMS provides for two separate types of agreements, 'AGREEMENTS' created pursuant to Article IV (3) concerning Appendix II species and 'agreements' pursuant to Article IV (4) for any migratory population. ${ }^{138}$ Guidelines for AGREEMENTS are set out in Article 5 of the CMS and provide for extensive measures to be applied to the conservation of the species the subject of the agreement. The obligation on parties in respect of AGREEMENTS is to 'endeavour to conclude' where they would be of benefit and to give priority in creation to species with unfavourable conservation status. ${ }^{139}$ This explains why the black petrel is the sole case study species to be the subject of an AGREEMENT, to which New Zealand is a party, which will be discussed in the following section. The bar-tailed godwit is subject to an AGREEMENT for part of its range through inclusion in the African Eurasian Waterbirds Agreement (AEWA), ${ }^{140}$ but New Zealand godwits are not 
within this range and therefore do not receive the additional protection of a binding agreement. For godwits in the South Pacific any coverage is pursuant to the nonbinding flyways agreement of the Partnership for the East-Asian Australasian Flyway $^{141}$ which sits outside the CMS. The Partnership is an informal initiative and the partners are drawn from governmental and non-governmental agencies and the international business sector. Conservation of migratory waterbirds for the benefit of people and biodiversity is the key goal of the Partnership and the 2012-2016 EAAFP Implementation Strategy sets out a flyway wide framework to achieve the goal and objectives of the Partnership. ${ }^{142}$

\subsection{Agreement on the Conservation of Albatrosses and Petrels}

In contrast to the position of the godwit, New Zealand is a party to the Agreement on the Conservation of Albatrosses and Petrels (ACAP) and the black petrel is listed pursuant to Annex 1 as one of the 30 species to which the Agreement applies. ${ }^{143}$ ACAP creates important binding obligations that elevate protective requirements for this species. ACAP's objective is to achieve and maintain a favourable conservation status for albatrosses and petrels. ${ }^{144}$ ACAP details a range of species protection measures in conjunction with other methods employed to protect and restore habitat. Parties are required to apply a precautionary approach and, where there are threats of serious or irreversible impacts, lack of full scientific certainty should not be used as a reason for postponing conservation measures. ${ }^{145}$

Elimination or control of non-native species detrimental to albatrosses and petrel is identified as a priority, as is the requirement to develop and implement measures to prevent, remove, minimise or mitigate the adverse effects of activities that may influence the conservation status of albatrosses and petrels. ${ }^{146}$ Black petrel no longer breed on mainland New Zealand sites, due in no small part to the impact of alien invasive species. ${ }^{147}$ Control of predators to levels compatible with successful breeding on mainland sites, would support restoration of the species to former range. ACAP also provides explicit support for implementation of the actions elaborated in the UN Food and Agricultural Organisation International Plan of Action for Reducing Incidental Catch of Seabirds in Longline Fisheries. ${ }^{148}$ Furthermore, considerable associated work is carried out with agencies such as the Commission for the Conservation of Antarctic Marine Living Resources (CCAMLR).

Partnership for the Conservation of Migratory Waterbirds and the Sustainable Use of their Habitats in the East Asian-Australasian Flyway, 'Partnership Document' (2006) < http://www.eaaflyway.net/documents/key/eaafp-partnership-doc-v13.pdf> accessed 20 June 2015.

142 East Asian-Australasian Flyway Partnership Implementation Strategy 2012-2016, Adopted by the Sixth Meeting of the Partners Palembang, Indonesia, 21 March 2012.

143 CMS Secretariat, The Agreement on the Conservation of Albatross and Petrel (2001) as Amended by the Fourth Session of the Meeting of the Parties, Lima, Peru, 23-27 April 2012.

144 art II (1).

145 art II (3).

146 art III (1) (b) \&(c).

147 R Francis and EA Bell, Fisheries Risks to the Population Viability of Black Petrel (Procellaria parkinsoni) (2010) 4; Wallace (n 4) ch 4. art III (1). 
Annex 2 of ACAP constitutes an Action Plan: in terms of species conservation, it prohibits the use of and trade in albatross and petrel, or their eggs, and fosters the development and implementation of conservation strategies for particular species or groups. ${ }^{149}$ ACAP further supports the control and, where possible, eradication of non-native taxa detrimental to petrel populations. ${ }^{150}$ Incidental bycatch is also targeted and Parties to ACAP are obliged to take appropriate measures to reduce or eliminate the mortality of albatrosses and petrels resulting incidentally from fishing activities. $^{151}$

The Annex to ACAP contains important habitat protection measures for including management plans in protected areas and pollution control at sea. ${ }^{152}$ Parties are also urged to develop management plans for the most important foraging and migratory habitats, although the scope of these is potentially limited to pollution avoidance and sustainable marine living resources. ${ }^{153}$ Implementation of management plans in the New Zealand context, would benefit the black petrel.

Where damaging fishing practices are occurring in specific marine areas and critically impacting on a species, Clause 2.3 .3 supports a spatial and/or temporal zoning restriction upon those fishing practices. Conservation priorities have also been identified in reliance of a recently developed prioritisation framework, designed to enable conservation effort to be directed at land-based and at-sea threats that are considered to warrant conservation management priority. Several fisheries that impact on the black petrel are identified as priority threats, ${ }^{154}$ although a recent report suggests that the assessment has excluded a fishery generating the highest proportion of risk to the bird. ${ }^{155}$ Implementation of spatial and temporal zones is a measure which would significantly benefit the black petrel. ${ }^{156}$ Greater visibility and implementation of clause 2.3.3 and Annex $1 \mathrm{cl}$ 3.2.1 is needed.

ACAP's Annex is one of few international instruments that specifically considers the issue of disturbance, creating clear obligations to minimise disturbance and to keep some areas in both marine and terrestrial habitats free of disturbance. ${ }^{157}$ In consideration of tourism, particularly in relation to proximity to breeding sites, the stronger standard of avoidance is adopted as an alternative to just minimising the impacts of disturbance. ${ }^{158}$

CMS and ACAP instruments can significantly benefit the case study species because they have a range of well-targeted protective measures to be applied across

Annex 2, cl 2.2.1 \& $\mathrm{cl}$ 2.3.1.

Annex 2, cl 2.3.1 \& cl 2.3.2.

ACAP (2012), ACAP Conservation Priorities, MoP4 Doc 17 Agenda Item 7.4 (2012).

Baird and Bell (n 113) 1.

Black Petrel Action Group, Black Petrel Briefing Note: Ministers and Advisors (2013). The benefits of effective marine spatial planning are also recognised by the Parties to the CBD, see for example: (2012) 'Marine and coastal biodiversity: sustainable fisheries and addressing adverse impacts of human activities, voluntary guidelines for environmental assessment, and marine spatial planning' Decision XI.18. Note also that fishing is excluded from restriction under the Exclusive Economic Zone and Continental Shelf (Environmental Effects) Act 2012 by s 20(5)(a) of that Act. 
Range States, they create species-specific agreements, they raise the profile for listed species which induces heightened protection and potential funding, they contain obligations regarding research and monitoring and they focus on specific threats such as bycatch and disturbance. Of particular importance is the decision made to 'commence engagements with a number of Regional Fishery Management Organizations (RFMOs), which manage high-seas fisheries affecting southern seabirds. ${ }^{159}$

\subsection{The Reduced Effect of the CMS and ACAP}

As with Ramsar and the CBD, CMS and ACAP are limited by a lack of force and influence. The instruments could be considerably strengthened by applying an active precautionary principle, strengthening the requirements for prevention of harm and requiring avoidance of adverse effects. This is clearly demonstrated in New Zealand by the current level of threat suffered by the black petrel from fisheries bycatch. The obligation to reduce, in contrast to eliminate fisheries bycatch mortality (or at least reduce to a level consistent with species recovery/increase), provides an insufficient standard to relieve the black petrel of the current significant burden arising through incidental mortality. For the petrel stronger measures are required, in particular spatial zoning measures creating temporary fishing restrictions. The privileging of the fishing industry is evident from the standard of control applied to incidental mortality, and a clear contrast can be drawn between this and the requirement of avoidance of disturbance through tourism.

The CMS is uneven in reach because selectivity is premised on endangerment. Accordingly, only those species that are critically placed receive the benefit of Appendix I listing. Prioritising species protection on endangerment is the foremost contemporary approach; ${ }^{160}$ however, this poses risks for those species outside of this category. The intent of the CMS and related agreements is to ensure that species are protected as they pass through other jurisdictions and to achieve a degree of consistency in the protective measures applied across the range. Yet, seeking this consistency between migratory species unwittingly creates inconsistencies with species that do not migrate.

In principle, through the action of the CMS and ACAP, the black petrel is privileged in contrast to the other case study species. As a result of ACAP, the black petrel has been the subject of a species assessment, ${ }^{161}$ which includes consideration of conservation status, breeding biology, conservation listings and plans, population trends, threats, distribution and, importantly, key gaps in the species assessment. Accurate estimates of breeding population and distribution together with details of foraging range are highlighted as areas to augment understanding to enable better protection of the species. The assessment provides a valuable focus on the species,

160 Alexander Gillespie, 'Animal Ethics and International Law' in Peter Sankoff and Steven White (eds), Animal Law in Australasia: A New Dialogue (Federation Press 2009) 352.

161 Agreement on the Conservation of Albatrosses and Petrels, 'ACAP Species Assessment: Black Petrel Procellaria Parkinsonii’ (2009) < http://www.acap.aq/acap-species> accessed 20 June 2015. 
particularly where a recovery plan pursuant to the Wildlife Act 1953 is not in place, as is the case of the black petrel.

That aside, the black petrel population has been decimated to such an extent that it now only survives on two offshore islands and within very specific locations. ${ }^{162}$ Why, then, would a restriction 'to prevent, remove, compensate for or minimize, as appropriate, the adverse effects of activities or obstacles that seriously impede or prevent the migration of the species ${ }^{, 163}$ not apply to that species? To strengthen the effect of the CMS it is recommended that Appendix 1 standards be extended to all 'threatened species'. Given that the standards already provide 'leeway' for implementing nations (for instance, 'minimise as appropriate'), such a measure would not be unduly onerous.

While the black petrel has the benefit of ACAP, this agreement covers all albatross but does not cover all petrel ${ }^{164}$ or other migrating New Zealand species. The sooty shearwater and the bar-tailed godwit are excluded from consideration despite threat assessments revealing significant potential for loss on migration routes. The sooty shearwater may be a populous species, but it suffers one of the highest rates of bycatch in New Zealand fisheries. ${ }^{165}$ The bar-tailed godwit, within the New Zealand range, is not covered by binding flyways protection despite development activity occurring along its migration routes, particularly staging posts in the Yellow Sea, of a scale which significantly threatens the species.

On a side note, the position of the wrybill deserves consideration. The wrybill is not contemplated by the CMS because it is an internal migrant so, despite facing many similar obstacles, it cannot gain additional protection from this international source. While the wrybill enjoys the more general protection of the $\mathrm{CBD}$, it lacks the protective focus regarding migration impediments and a species assessment, made all the more valuable in the absence of a recovery plan under the Wildlife Act 1953. Effort needs to be applied to ensure domestic law adequately covers the threats faced by internal migrants and reflects, if not strengthens, measures available under CMS and ACAP.

Although there are 119 Parties to the CMS, membership is not universal, and neither the People's Republic of China nor the Republic of Korea is a member. ${ }^{166}$ This is significant for the godwit, given the extent of habitat loss arising through reclamation and development at key staging posts in these countries.

Similarly with ACAP, only $45 \%$ of the Range States are party to the Agreement, and eight of the Range States are not party to the CMS including the People's Republic of China, the Russian Federation and the USA. ${ }^{167}$ Coverage for the black petrel, though, is reasonable. New Zealand (its only known breeding ground) is a

162 Francis and Bell (n 147) 4.

163 CMS art III (4) (b).

164 CMS Scientific Council Flyways Working Group, A Review of CMS and Non-CMS Existing Administrative and Management Instruments for Migratory Birds Globally in A Review of Migratory Bird Flyways and Priorities for Management (CMS Techncial Series Publication No 27 2014) 46, <http:// www.cms.int/en/workinggroup/working-group-flyways > accessed 28 June 2015.

165 Richard and Abraham (n 112) 18.

166 Parties to the Convention on the Conservation of Migratory Species of Wild Animals and its Agreements, <http://www.cms.int/en/legalinstrument/cms > accessed 28 June 2015. 
Party as are Australia, Equador and Peru, which are known as foraging Range States. The bird is, however, also known to forage within the Exclusive Economic Zones of Columbia, El Salvador, Guatemala, Mexico, Panama and the USA, none of which are Parties to ACAP. ${ }^{168}$

This lack of universal membership of Range States creates an immediate problem as regards compliance and migratory species, but a second issue is that of scale. The foraging range of the black petrel is extensive, reaching west to Australia and east to South and Central America, but also incorporates the vast tracts of ocean. The characterisation of compliance with international agreements as 'paper compliance' in contrast to actual compliance is a further issue limiting treaty effectiveness. ${ }^{169}$

\section{CONCLUSION}

Ramsar, the CBD, the CMS and ACAP each canvass a range of important issues and related responses which impact on the case study species. The Conventions are well directed and propose and drive a wide range of important measures. Despite this, evidence suggests that the instruments and their implementation are currently insufficient to stem biodiversity loss. There are three main points to conclude from the review.

First, the examination shows that the agreements are focused upon the most significant threats that face the case study species, but that the measures of themselves are not particularly compelling. A failure to adopt a strong active stance to precaution and prevention in the management of threats to species weakens the rigour of measures applied. Moreover, considerable leeway is left for any implementing nation, thus impacting on the extent of burden distributed to species. It can be argued that stronger obligations imposed at the international level may produce greater efforts at the national level, and that without leadership at the international level, national efforts may falter. Yet this is only part of the problem, as this article demonstrates that, despite some significant effort on behalf of DOC and other administering agencies in many instances the implementation effort of New Zealand is deficient. This is both in relation to specific obligations of agreements and more general intent. Significantly more could be made of Ramsar to benefit birds in New Zealand, through greater engagement, and implementation. For species protection, the current threat posed to the black petrel through fisheries bycatch provides evidence of ineffectual instruments and insufficient implementation methods.

Active implementation of the Aichi targets would benefit all case study species. The Aichi targets and their translations represent a step up in boldness of approach, but if they are to resound effectively in the Anthropocene contracting nations must apply strong implementing measures to secure the targets. Endorsement by nationstates of the principle of non-regression ${ }^{170}$ is recommended to prevent slippage, a problem looming in relation to environmental protection in New Zealand as the 
government debates amendment to the guiding principles of the RMA. ${ }^{171}$ Greater efforts are required in order to give effect to the targets in a policy environment dominated by notions of 'wise use' and sustainable development. For New Zealand achieving the Aichi targets will be dependent upon addressing the ways in which the law currently privileges resource use to the detriment of species due to insufficient environment standards, sectoral defences, widespread externalities and deficient implementation. Heightened protection through spatial zoning would benefit the case study birds together with more nuanced spatial zoning in protective reserves and transition areas.

Secondly, the article illustrates an inconsistent and fragmented approach to threatened species. An examination across the three instruments displays the unevenness of approach. Ramsar is focused upon a specific ecosystem type, and protecting the values within it, but site selection and implementation produce an ad hoc approach to protecting the site values, and the species for which the site provides habitat. Insufficient management of external influences results in the persistence of a range of threats to the case study species and, potentially, the same can be said for insufficient on-site management.

CMS and ACAP elevate standards of protection for particular species, according to remit and premised upon endangerment. While it is acknowledged that this is the intention and purpose of the agreement, it nevertheless creates a separate and fragmented layer of protection. For the black petrel it is clearly vital that threats such as bycatch are addressed quickly and with priority and ACAP provides welcome support. Yet just because the sooty shearwater is a numerous species does not seem a sufficient reason for it to be excluded from Appendix II, particularly where it is a species of significant cultural importance. In the same vein, the godwit and the black petrel arguably deserve protection from obstacles that prevent or hinder migration and other related intentions, yet this protection is reserved for international migrant species whose plight is critical. The management of disturbance is another example which receives uneven treatment.

Due to its lack of immediate endangerment the godwit found on New Zealand shores, misses out on a protective agreement, despite being a migrant suffering considerable loss at its international staging posts. Of concern are the scale of this loss and the potential agility of an international agreement to respond to this. In addition, lack of universal membership of both ACAP and CMS limits reach and consistency of approach.

Thirdly, there is a lack of integration across the agreements, a problem accentuated by fragmentation in national approach. If not coordinated and consistent at an international level, it is much less likely that an integrated approach will be taken at a national level. Although, measures are in place to increase harmonisation, the ad hoc development of treaties, related institutional frameworks and extensive guidance material underscore the need for implementing nations to introduce universal and integrated approaches to protecting threatened species otherwise certain species may slip between the cracks of protection. 


\section{ACKNOWLEDGEMENTS}

My grateful thanks to Al Gillespie, Barry Barton, Robyn Longhurst, Ben Boer, Nicola Wheen and Iain White for valuable comments on earlier drafts, and to the anonymous reviewers for this journal. Their well-directed comments combined with Liz Fisher's meticulous editing skills have greatly improved this research. 